\title{
Evaluation of the Energy Consumption in Mediterranean islands Hotels: Case study: the Balearic Islands Hotels
}

\author{
A. Moiá-Pol ${ }^{1}$, Michalis Karagiorgas ${ }^{2}$, D. Coll-Mayor ${ }^{1}$, V. Martínez-Moll ${ }^{1}$, Carles Riba-Romeva ${ }^{3}$
}

\author{
1 Department of Physics - Mechanical Engineering Area \\ University of Balearic Islands, Ctra. Valldemossa km. 7, 5, 07122 Balearic Islands (Spain) \\ Phone:+34 971 171374, fax:+34 971 173426, e-mail: andreu.moia@uib.es \\ 2 Centre for Renewable Energy Sources (CRES), \\ 19th km Marathonos Avenue, Pikermi, GR-19009, Greece. \\ 3 Centre de Disseny d’Equips Industrials, Universitat Politècnica de Catalunya (UPC) \\ C/ Llorens Artigues, 4-6 Edifici U, planta 0 , 08028 Barcelona, Spain
}

\begin{abstract}
Hotels rank amongst the highest energy consumers in the tertiary building sector [4]. Improved service quality mandates that hotel buildings, facilities and installations are maintained to the highest standards, thus renovations are becoming common in order to keep up with competitivity. This offers great opportunities for promoting energetically efficient measures, exploitation of renewable energy sources (RES) and rational use of energy (RUE) in the hotel sector. The Balearic Islands are one of the first tourist destinations with about half million beds available. Many successful hotel companies that have emerged during the 70's and the 80's are now exporting their experience to other expanding destinations. The Balearic Government has studied about 200 hotels in order to investigate the levels of energy consumption and sustainability among them. This research has been performed with the intention of appreciating the opportunities of efficiency improvement of the energy facilities so as to supply, as much as possible, with RES the energy demand.
\end{abstract}

\section{Key words}

Energy Audits, Hotel, Energy Efficiency (EE), Renewable Energy Source (RES), Rational Use of Energy (RUE).

\section{Introduction}

The energy must no longer be considered as a strictly national issue. Climate change, brought about notably by the burning of fossil fuels, is a serious threat to all our countries.

Figure 0 . World requirement for air conditioning or space heating[1].

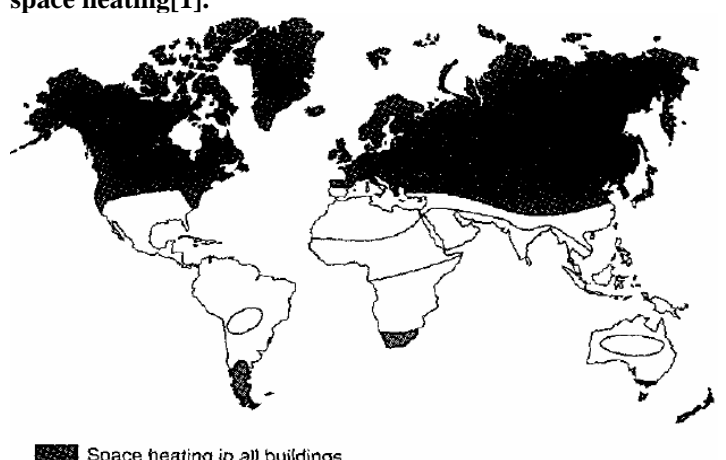

Space heating in all buildings

Air-conditioning necessary for not native born
Energy consumption in hotels is amongst the highest in the non-residential building sector in absolute values (for example, $215 \mathrm{kWh} / \mathrm{m}^{2}$ in Italy, $287 \mathrm{kWh} / \mathrm{m}^{2}$ in Spain, $280 \mathrm{kWh} / \mathrm{m}^{2}$ in Greece, $420 \mathrm{kWh} / \mathrm{m}^{2}$ in France) [4]. The difference lies on the efficiency process and the unitary consumption of the users (especially in thermal necessities when considering the diverse external temperatures and divergent comfort temperature between the natives and the rest).

Considering the fact that the building's operational costs will grow with time and that problems get worse unless some actions are taken, there is a clear need for proper maintenance, refurbishment or retrofitting (upgrading) of the building. Such actions should focus on the structural building elements and installations that can also improve the energy performance and the indoor environmental quality.

The hotel sector is uniquely placed to provide the impetus for change in business behaviour within tourism, because of its multiplier effect on guests, staff and suppliers as well as the central role that hotels play within local communities. Additionally, possible energy conservation techniques for RUE and exploitation of RES have a unique demonstration potential and a high exposure to millions of people that visit hotels at one time or another.

The Mediterranean region presents favourable conditions for the application of Solar Energy. Most of the existing hotels in this area basin have more than 20 years. Low quality buildings, at least for today's standards, energy consuming installations, low performance equipment, as well as unsustainable exploitation of the natural resources, are common features of these constructions. Hotels are usually located in areas with high seasonal energy loads, and frequently with high energy cost and low supply (i.e. islands). 


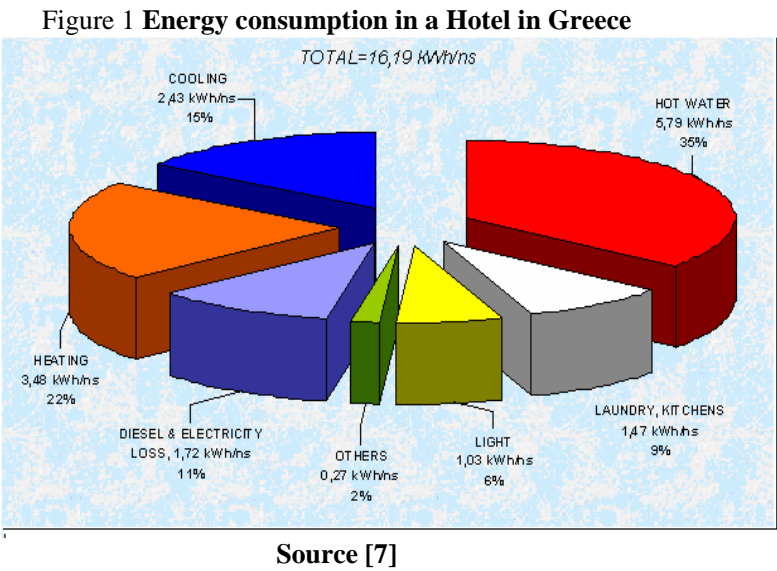

Hotels within the Mediterranean area have similar consumptions because of the similar technology, climate and clients. However, the unitary energy consumption per night spend changes a lot depending on various factors; facilities provided, category of hotel, occupancy, geographical situation, weather conditions, nationality of clients (habits), architecture of the building, design and control of the installations, among others. The biggest difference lies in the source of energy, depending on the local policies of energy prices and services of energy companies.

Figure2. Renewable energy sources in the E.U.

\begin{tabular}{|c|c|c|c|c|c|c|c|c|c|c|}
\hline Member State & $\begin{array}{l}\text { \% Groses } \\
\text { Inland } \\
\text { Consump. } \\
\text { tion }\end{array}$ & $\begin{array}{l}\text { \% Inling } \\
\text { Power } \\
\text { Genera. } \\
\text { fion }\end{array}$ & 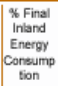 & $\begin{array}{l}\begin{array}{l}\text { Produc- } \\
\text { tion Ktoe }\end{array} \\
\text {. }\end{array}$ & $\underset{\text { Hydro }}{\infty}$ & $\begin{array}{c}\% \\
\text { Biomass }\end{array}$ & $\begin{array}{l}\text { W } \\
\text { Wind }\end{array}$ & $\begin{array}{l}\text { Solar } \\
\text { Solar }\end{array}$ & Geoth & $\begin{array}{l}\text { sh } \\
\text { Other } \\
\text { R.E. }\end{array}$ \\
\hline France & $7.2 \%$ & $7.4 \%$ & $6.6 \%$ & 17,553 & $35.7 \%$ & $63.5 \%$ & $0.0 \%$ & $0.1 \%$ & $0.7 \%$ & $0.0 \%$ \\
\hline Germany & $2.9 \%$ & $4.2 \%$ & $2.1 \%$ & 9,942 & $17.0 \%$ & $65.2 \%$ & $4.8 \%$ & $0.8 \%$ & $0.1 \%$ & $12.2 \%$ \\
\hline Greece & $5.7 \%$ & $4.6 \%$ & $6.0 \%$ & 1.470 & $28.3 \%$ & $62.1 \%$ & $1.0 \%$ & $8.4 \%$ & $0.1 \%$ & $0.0 \%$ \\
\hline Italy & $8.2 \%$ & $15.1 \%$ & $5.4 \%$ & 13,706 & $28.5 \%$ & $50.4 \%$ & $0.3 \%$ & $0.1 \%$ & $20.4 \%$ & $0.4 \%$ \\
\hline Portugal & $13.1 \%$ & $18.0 \%$ & $11.6 \%$ & 2,737 & $22.8 \%$ & $70.6 \%$ & $0.4 \%$ & $0.7 \%$ & $2.6 \%$ & $3.0 \%$ \\
\hline Soain & $5.8 \%$ & $7.3 \%$ & $5.1 \%$ & 6,205 & $31.7 \%$ & $62.8 \%$ & $3.8 \%$ & $0.5 \%$ & $0.1 \%$ & $1.2 \%$ \\
\hline European Union & $6.1 \%$ & $10.9 \%$ & $4.4 \%$ & 86,553 & $30.3 \%$ & $62.1 \%$ & $1.4 \%$ & $0.4 \%$ & $3.5 \%$ & $2.3 \%$ \\
\hline
\end{tabular}

The solar energy used compared with the total energy corresponds to the $0,5 \%$ in Spain, 0,7\% in Portugal and $0,1 \%$ in Italy. This makes it insignificant compared with the 8,4\% of Greece, especially if one considers that all the above mentioned countries have similar solar radiation. [5]

During summer all these areas have the maximum occupation; when the solar radiation and the temperature reach their maximum values the energy consumption in the HVAC arrives to most of the hotels to the $50 \%$ of their total consumption. [6]
Figure 3. Energy consumption in Balearic Island's Hotel vs Solar Radiation

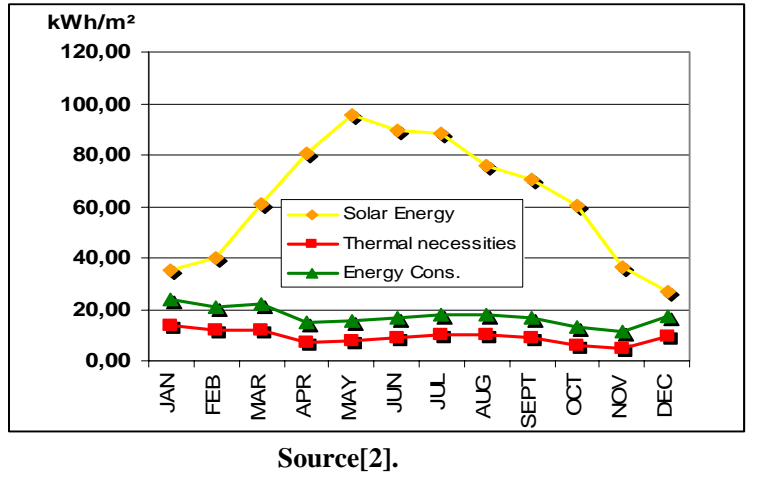

\section{Objectives}

The objective of the energy audits is to check out the energy management of the hotel owner and find out occasional tactics that can improve the energy efficiency and the potentials of installing RES. The steps to be taken are; firstly to analyse the energy audits and the hotel consumption, secondly to appreciate the rational use of energy (RUE) in the hotels, and finally to find out opportunities of improvement of the energy efficiency and renewable energy sources (RES).

\section{Case study}

The Balearic Islands are a typical example of tourist islands, with more than 2.500 Hotel industries that implies an increase of $50 \%$ of the population at high season [10]. There is a high use of no renewable energy; almost $97 \%$ of Balearic's energy comes from fuel and coal, and all is imported. The Balearic Government, during the last years has performed energy audits at hotels within the archipelago, which represents the $10 \%$ of the hotels buildings and corresponds to more than 12 millions of nights spend.

Table 1 . Resume of Energy Audits Hotels in the Balearic

\begin{tabular}{|c|c|c|c|c|}
\hline $\begin{array}{c}\text { Source of } \\
\text { Energy }\end{array}$ & Electricity & $\begin{array}{c}\text { Gas- } \\
\text { LPG }\end{array}$ & Diesel & Total \\
\hline $\begin{array}{c}\text { Energy Cost } \\
\text { (€/ns) }\end{array}$ & 0,80 & 0,05 & 0,17 & 1,02 \\
\hline $\begin{array}{c}\text { Energy Cost } \\
\text { (\%) }\end{array}$ & $\mathbf{7 8 \%}$ & $\mathbf{5 \%}$ & $\mathbf{1 7 \%}$ & $\mathbf{1 0 0 \%}$ \\
\hline $\begin{array}{c}\text { Energy } \\
\text { consumption } \\
(\%)\end{array}$ & $\mathbf{5 4} \%$ & $\mathbf{1 0} \%$ & $\mathbf{3 6} \%$ & $\mathbf{1 0 0} \%$ \\
\hline Maximum & 45,44 & 31,80 & 15,52 & 71,72 \\
\hline Minimum & 0,65 & 0,00 & 0,00 & 7,08 \\
\hline $\begin{array}{c}\text { Average } \\
\text { Energy } \\
\text { consumption } \\
\text { (kWh/ns) }\end{array}$ & $\mathbf{8 , 2 8}$ & $\mathbf{1 , 5 5}$ & $\mathbf{6 , 2 1}$ & $\mathbf{1 5 , 3 9}$ \\
\hline \multicolumn{4}{|l|}{ Source[2]. Years $\mathbf{2 0 0 1 - 2 0 0 3}$} & \\
\hline
\end{tabular}


From these audits we discern that the energy more used at the Islands' hotels is the electric, producing the $54 \%$ of the total energy consumption. The measured average during the year is about 8,3 kWh/ns for electricity in a total of 15,39 kWh/ns (see table1). Gas and diesel are not used in all the hotels; instead, all of them make use of the electric energy. The energy cost per night spend is comparatively low with the global management, oscillates between 4-10\% from the total. [9]. Approximately the same average-totals seem to be valid for Greece compared to the Balearic figures (fig.1 and Table1 resp.)

According to the opening periods, hotels can be distinguished into the following categories, energetically speaking: hotels opening all the year round and hotels opening only during the high season. Once this distinction is made, more factors relevant to the services provided have to be considered, like the use of calefaction and air conditioning systems or food service (not available in all hotels).

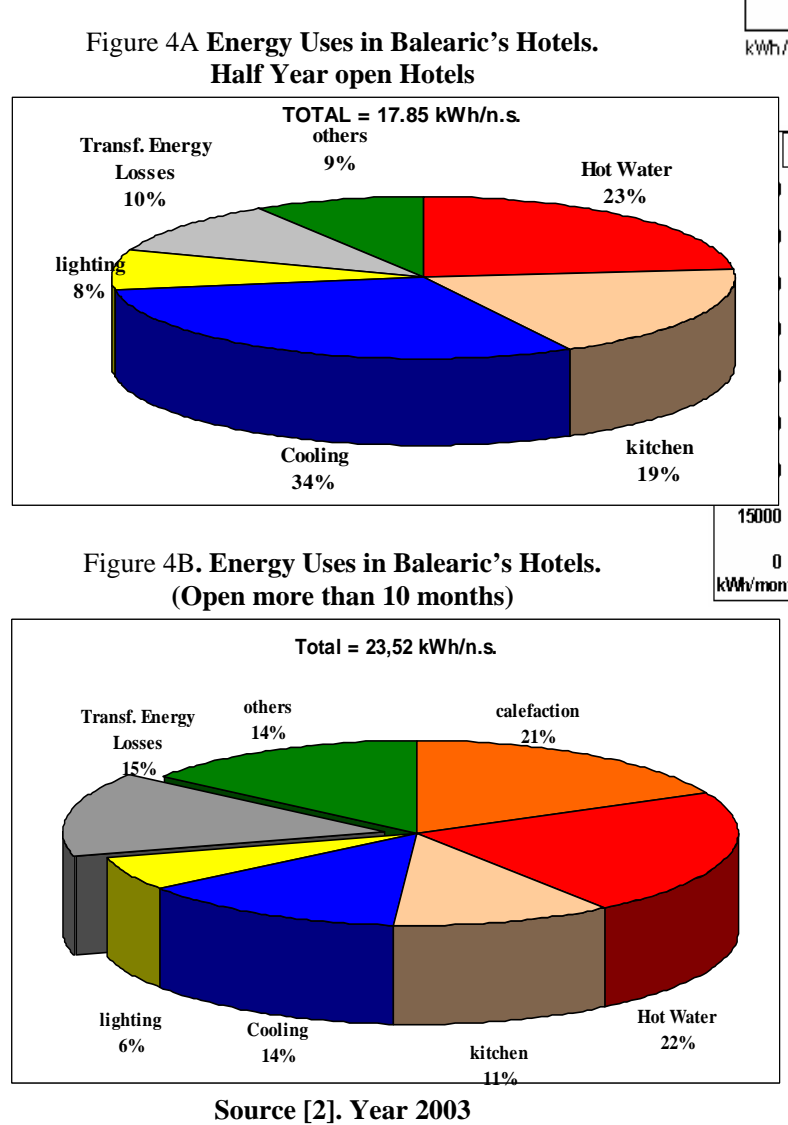

However, there are a lot of disparities. The most important factors that until now influence more the unitary consumption are the hotel category, the HVAC service and the geographical situation of the hotel. On the other hand, the increase of quality so as to make the sector more competitive results into making more similar the services provided and the kind of clients hosted at the Balearic Islands. Consequently, the energy consumption between medium and high category hotels tends to be the same. Facilities that were considered as luxurious now are included in basic services. At the Islands and coastal areas the hotels open only six months, from mid-April until mid-October, while there is a considerable number of open hotels all year - round.

Figure 5A. Energy consumption per month in 400 beds hotel at the Balearic's Is. (KWh)

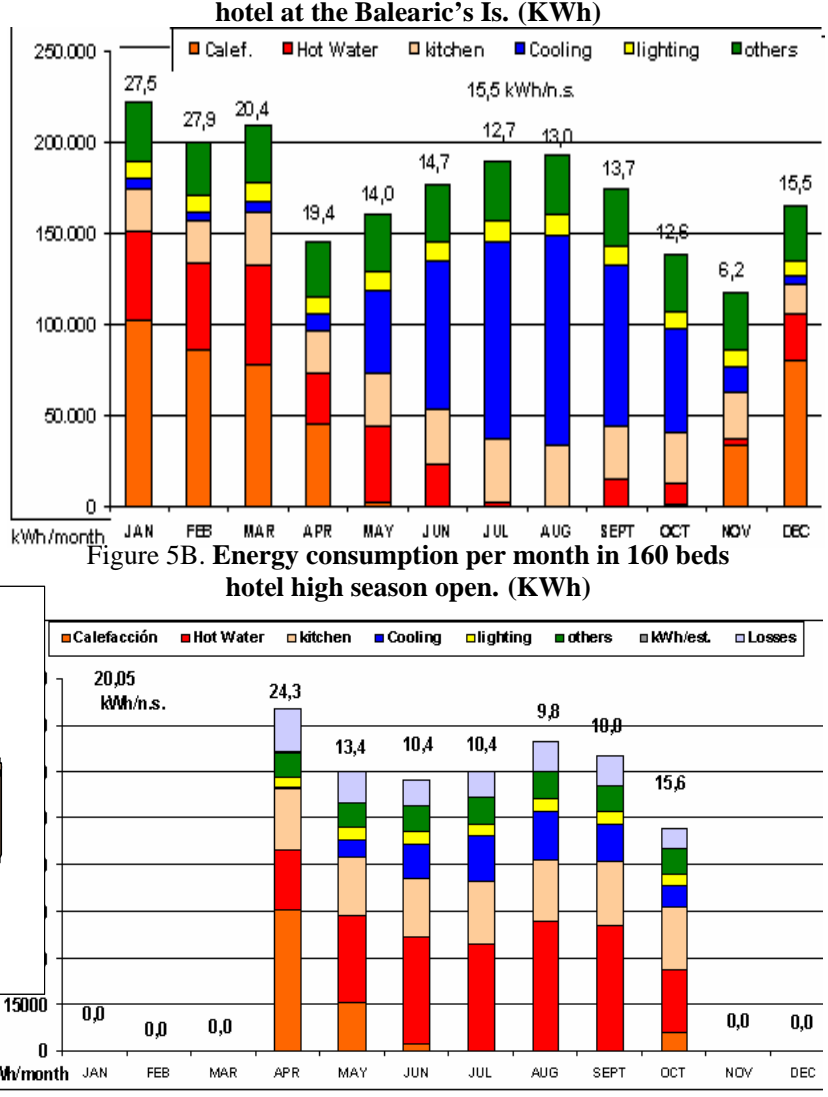

Source[2]. Year 2003

The most important difference between the two kinds of hotels is the thermal energy spent for calefaction. The use of electricity is destined principally for air conditioning [5A] which makes energy consumption per night spend vary during the year.

There are a lot of studies and software that have calculated the energy savings and feasibility of the incorporation of systems exploiting RES and the adoption of techniques for RUE in different tourist areas and countries. The main solutions are the improvement of the efficiency process of the systems technology and the management of these systems. Differences as well exist among hotels within the same category and facilities, depending on the installations' design, technology, maintenance and control. This difference in terms of energy consumption between an environmentally friendly hotel that has implemented measures to preserve natural 
resources and a hotel built during the 1970s and 1980 s and not yet refurbished can be from 30\% to $60 \%$ with all other factors being equal (same climate, same needs).

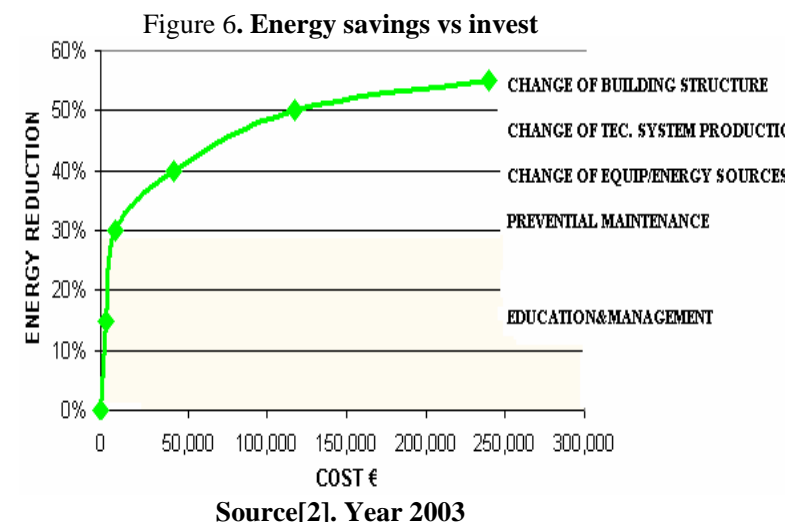

Energy conservation measures in hotels have to be carefully selected in order not to endanger the quality of the services provided and at the same time safeguard the first law: not waste energy. The highest energy demand in hotels comes from HVAC devices, raising the demand of electricity which is the common source of energy in all hotels and the easiest to save. Accordingly, priority should be given to control energy used in guest rooms, for example, by using simple controls to ensure that practically all electrical appliances are turned off when guestrooms and corridors are unoccupied. This can result to a potential energy saving between 15 to $30 \%$.

Table 2 . Identification of savings measures in $\mathbf{4 0 0}$ beds hotel at the Balearic's Is.

\begin{tabular}{|c|c|c|c|c|c|}
\hline \multirow[b]{2}{*}{ ACTION } & \multirow{2}{*}{$\begin{array}{c}\text { Invest } \\
€\end{array}$} & \multicolumn{3}{|c|}{ SAVINGS per year } & \multirow{2}{*}{$\begin{array}{l}\text { pay- } \\
\text { back } \\
\text { years } \\
\end{array}$} \\
\hline & & MWh & $\mathrm{Kg} \mathrm{CO}_{2}$ & $€$ & \\
\hline $\begin{array}{l}\text { Change electricity } \\
\text { company conditions }\end{array}$ & 6.977 & 0 & 0 & 5.312 & 1,31 \\
\hline $\begin{array}{l}\text { Reduce Refrigeration } \\
\text { losses and frost } \\
\text { control }\end{array}$ & 492 & 13,4 & 3,8 & 828 & 0,60 \\
\hline Rational regulation & 600 & 14,0 & 4,0 & 863 & 0,70 \\
\hline $\begin{array}{l}\text { Isolation } \\
\text { improvement }\end{array}$ & 264 & 21,5 & 6,2 & 1.327 & 0,20 \\
\hline $\begin{array}{l}\text { Thermodynamic } \\
\text { valves }\end{array}$ & 2.338 & 22,5 & 6,5 & 1.393 & 1,68 \\
\hline Lighting regulation & 12 & 23,7 & 6,8 & 1.467 & 0,01 \\
\hline Improving of boilers & 345 & 28,7 & 8,3 & 1.773 & 0,19 \\
\hline $\begin{array}{l}\text { Control of Hot water } \\
\text { and calefaction }\end{array}$ & 163 & 52,0 & 15,0 & 3.217 & 0,05 \\
\hline $\begin{array}{l}\text { Heat recovering/water } \\
\text { condenser }\end{array}$ & 6.750 & 106,0 & 30,5 & 6.551 & 1,03 \\
\hline $\begin{array}{l}\text { Change source of } \\
\text { energy }\end{array}$ & 18.000 & 144,5 & 41,6 & 8.937 & 2,01 \\
\hline $\begin{array}{l}\text { Change of bulbs and } \\
\text { electronics }\end{array}$ & 230 & 197,6 & 56,9 & 12.214 & 0,02 \\
\hline $\begin{array}{l}\text { Solar Energy use for } \\
\text { hot water }\end{array}$ & 124.000 & 312,2 & 89,9 & 19.304 & 6,42 \\
\hline
\end{tabular}

For thermal purposes there is a large variety of energy sources used; the most common are the fossil fuels especially for calefaction and hot water consumption, for sanitary use, services and kitchens. On the other hand the gas is used from the majority of hotels for the kitchen. This is certainly not done according to sustainable ${ }_{\mathrm{N}}$ criteria, because the boilers have less energy efficiency and the fossil fuels produce about a $25 \%$ more $\mathrm{CO}_{2}$ than the gas. The total energy consumption for hot water may represent between $12 \%-36 \%$ of the total energy consumption which varies according to the hotel category and weather conditions. Average annual energy consumption may reach 1300$5000 \mathrm{kWh}$ per bed. The potential average annual energy savings from solar collectors reach $550 \mathrm{kWh} / \mathrm{m}^{2}$ [9] of collector area. Thus they can be used to cover a significant part of the energy demand for sanitary and pool water heating (80\%), and if combined with absorption chillers, can also be used for cooling. The use of heat recovery from the cooling system (i.e. recover waste heat from cooling towers as useful energy) can also be used to reduce energy consumption for service hot water and swimming pool water heating. Additional benefits, in this case, originate by improved efficiency of the cooling towers and reduced operating hours that provide additional savings [8].

For a hotel, build at 70's, without control and with old technology, the average annual energy savings potential with co-generation can be $55 \%$. Only the change of source energy fuel by gas with condensation heaters can reach energy savings of a $20 \%$ and more than the $30 \%$ of $\mathrm{CO}_{2}$ emissions. With a low cost investment the energy savings can be 35\%.Unitary energy costs can be found in [9].

From the table 2, a representative size hotel of 400 beds, build at the 70's the annual energy savings can reach 315 MWh (22\%) only from the installation of solar collectors, changing the source of energy can reach an energy saving of the 415 MWh (30\%). The pay back of the initial investment in most of the cases is less than two years.

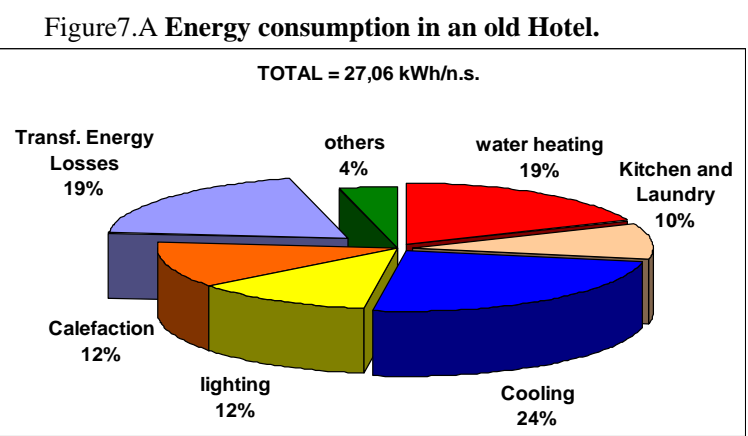


Figure 7B. Estimated fossil energy consumption applying RUE and RES in a hotel.

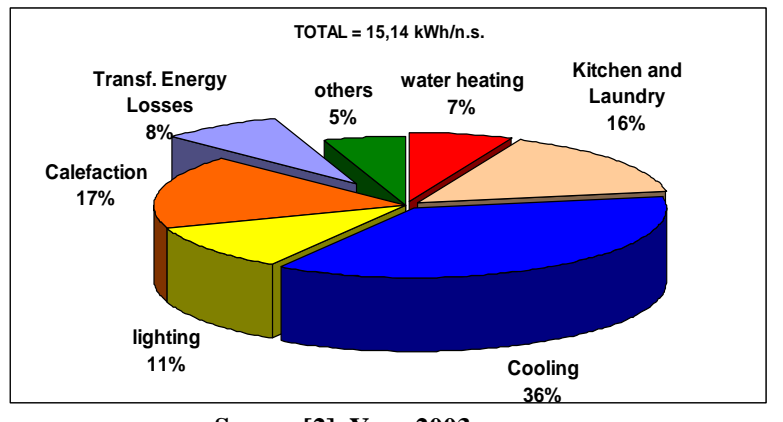

Source [2]. Year 2003

Applying a RUE and RES in old hotels can be a big economic, energetic and $\mathrm{CO}_{2}$ emissions reduction without change the comfort of the clients. Comparing the Figure number 7A with the number $7 \mathrm{~B}$ there can be seen a big difference in the energy consumption, from 27,06 kWh per night spend in an old hotel to $15,14 \mathrm{kWh}$ per night spend in a new hotel, there is a reduction of a $44 \%$ in the consumption of fossil energy. The energy losses can be reduced more than a $10 \%$.

\section{Conclusions}

The final energy consumption in the Balearic hotels varies from 7 up to $77 \mathrm{kWh} / \mathrm{ns}$, and the average is $15,4 \mathrm{kWh} / \mathrm{ns}$.

The above figures match the Greek conditions, since in Greek island type B hotels the final energy consumption varies from 5 up to $25 \mathrm{kWh}$ $/ \mathrm{ns}$, and the average is $16,19 \mathrm{kWh} / \mathrm{ns}$ [7].

A high amount of this energy consumed by the tourist sector is destined for thermal applications. This fact allows for large reduction on the fossil fuel used via solar energy facilities. The actual efficiency of the hotels of the Balearic Islands is lower that the $60 \%$, especially at the old hotels with a high unitary consumption.

A not considerably big investment can bring a potentially big energy reduction for the old hotels built at the 70's and 80's. In a significant 400 beds hotel with an investment lower than $10.000 €$ can be saved more than the $25 \%$ of the energy consumption, improving the energy efficiency, with a pay back lower than 6 years. The integration of RES in the energy production at hotels, especially solar heating and cooling technologies, seems an excellent challenge for hotel managers. [9].

In this way they can prove their adaptability for innovative and cost effective technologies resulting to a highly positive environmental impact [8].

The actual model of high dependence on fuel consumption and centralised electric plants is not sustainable. They have a lower efficiency (36\%) than the tri-generation systems (82\%)[3], because they can't use a big part of the thermal energy. Indeed, the tri-generation plants in hotel industries and residential areas can solve their thermal necessities (63\%). The direct consequence is that for the same energy consumption the tri-generation plants would consume almost a $50 \%$ less of fuel with a big reduction of $\mathrm{CO}_{2}$ emissions. The distributed bi and tri generation plants can serve for improve the efficiency of the system.

\section{Acknowledgement}

\section{Balearic Government, G.D. Energy. References}

[1] CADDET (Centre for the Analysis and Dissemination of Demonstrated Energy Technologies Energy) Efficiency Retrofitting of Residential Buildings (AR 18). March 1996

[2] DG de Energia de la Conselleria de Comerç, Industria i Energia del Govern Balear. Estadístiques i Auditories Energètiques 2000-2002. Palma de Mallorca (2003).

[3] D. Coll, E. García, V. Matas. “Combined Tri-generation/Solar Plant Supplying all the Energy needs in a High Tech-Park” in Proc. WREC VII, pp. 323.

[4] Argiriou AA, Balaras CA, Dascalaki E, Gaglia A, Gountelas G, Moustris K, Santamouris M, Vallindras M. Energy audits in public and commercial buildings in Greece, Proc. 3rd European symposium: soft energy action at the local level, Chios (Hellas), 11-14 September 1991.

[5] Boletín IDAE: Eficiencia Energética y Energías Renovables ( $\left.{ }^{\circ} 2,6\right)$ Depósito Legal: M-24028-2001, M-18505-2004.

[6] A. Moiá-Pol, Michalis Karagiorgas, V. Martínez-Moll, Carles Riba-Romeva. Energy Policy and an Action Plan for Renewable Energy Sources (RES) in Mediterranean islands Hotels: Policy and Energy audits in the Balearic Islands. Procc. International Conference on Energy Efficient CIUREE. Universidad Autónoma de Occidente. Calí (2004)

[7]M. Karagiorgas, V. Drosou, Th. Tsoutsos. «Solar Energy and RES for the Tourism Sector", International Conference "RES for Island: RES and RUE for Islands, Sustainable Energy Solutions”, 30-31 August 2004, Larnaka (Cyprus).

[8] XENIOS - a decision making methodology \& software for assessing refurbishment scenarios in hotels, Dascalaki E., Balaras C. , Aleo F., Cabot J., Caccavelli D., 
Casanovas X., Cladera A. , Lagoudi A., Martinez Tina , Moya A., Tsakmakidou K..

[9] Michaelis Karagiorgas, Theocharis Tsoutsos, Vassiliki Drosou, Stéphane Pouffary, Tulio Pagano, Germán Lopez Lara, José Manuel Melim Mendes. "HOTRES: Renewable energies in the hotels. An extensive technical tool for the hotel industry" article in press in Renewable and Sustainable Energy Reviews.

[10] IBAE. Les Illes Balears en Xifres 2001. Palma de Mallorca (2002). 